\title{
Pre-pregnancy BMI and intake of energy and calcium are associated with the vitamin D intake of pregnant Malaysian women
}

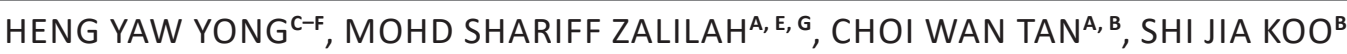

Department of Nutrition and Dietetics, Faculty of Medicine and Health Sciences, Universiti Putra Malaysia, Malaysia

A - Study Design, B - Data Collection, C - Statistical Analysis, D - Data Interpretation, E - Manuscript Preparation, F - Literature Search, G - Funds Collection

Summary Background. Adequate vitamin D intake during pregnancy is important for prevention of adverse pregnancy outcomes. Objectives. The present study aims to determine the intake and sources of vitamin $D$, as well as factors associated with vitamin $D$ intake among pregnant Malaysian women.

Material and methods. This cross-sectional study was conducted at the Seremban Maternal and Child Health (MCH) clinic, Negeri Sembilan. Women $(n=314)$ were measured for height and weight and interviewed for socio-demographics, obstetrics, dietary intake, source of vitamin $D$, intake of vitamin D supplements and physical activity.

Results. One-third of pregnant women were overweight (21\%) or obese (13\%) with a mean pre-pregnancy Body Mass Index (BMI) of $23.65 \pm 5.29 \mathrm{~kg} / \mathrm{m}^{2}$. The mean vitamin D intake of pregnant women was $11.54 \pm 0.45 \mu \mathrm{g} /$ day (diet $=6.55 \pm 4.43 \mu \mathrm{g} /$ day; supplements $=4.99 \pm 5.95 \mathrm{\mu g} /$ day) with approx. $74.5 \%$ of intake being above recommendation levels. Milk and milk products showed the greatest contribution to vitamin D intake (56.8\%). While women with higher energy (adjusted OR $=0.10,95 \% \mathrm{Cl}=0.01-0.87$ ) and calcium (adjusted $\mathrm{OR}=0.27,95 \% \mathrm{Cl}=0.11-0.67$ ) intake were more likely to have adequate vitamin $\mathrm{D}$ intake, obese women were less likely to have adequate vitamin $\mathrm{D}$ intake (adjusted $\mathrm{OR}=1.65,95 \% \mathrm{Cl}=1.72-3.79$ ).

Conclusions. Adequate intake of vitamin D was significantly associated with higher energy and calcium intake, but obese women tend to have inadequate intake. Further studies need to confirm these finding and the contribution of vitamin $D$ intake to vitamin $D$ status in pregnant Malaysian women.

Key words: pre-pregnancy BMI, energy intake, calcium intake, vitamin D intake.

Yong HY, Zalilah MS, Tan CW, Koo SJ. Pre-pregnancy BMI and intake of energy and calcium are associated with the vitamin D intake of pregnant Malaysian women. Fam Med Prim Care Rev 2017; 19(4): 417-423, doi: https://doi.org/10.5114/fmpcr.2017.70819.

\section{Background}

Vitamin D facilitates calcium absorption and plays a role in normal bone mineralization and bone growth by maintaining blood concentrations of calcium and phosphorus. In addition, vitamin D may play a role in modulation of neuromuscular, immune function and certain disease prevention, such as multiple sclerosis, type 2 diabetes and some cancers [1]. There is an increasing interest in the role of vitamin $\mathrm{D}$ nutrition during pregnancy, lactation and early infancy [2-4]. These studies implicate vitamin $\mathrm{D}$ deficiency during pregnancy as a significant risk factor for multiple adverse pregnancy outcomes related to both mothers and infants, including increased risk of rickets, atopic (asthma), autoimmune disorders (allergies), preterm birth and small-for-gestational-age (SGA) in infants, while for mothers, there is an increased risk of preeclampsia, gestational diabetes mellitus (GDM), osteoporosis and bone fractures [4-7].

The definition of optimal intake of vitamin $D$ is subject to much debate, and the recommendation level varies between countries. In developed countries, low vitamin D intake was observed at an average of $3.4 \mu \mathrm{g} /$ day among Scottish pregnant women [8], $2.0 \mu \mathrm{g} /$ day among Irish pregnant women [9] and 5.1 $\mu \mathrm{g} /$ day among Finnish pregnant women $[3,10]$. Similarly, low vitamin $\mathrm{D}$ intake among pregnant women was also reported in developing countries. Vitamin D intake among pregnant women in Iran was $1.2-2.3 \mu \mathrm{g} /$ day $[11,12]$.
Parity, pre-pregnancy BMI and ethnicity have been found to be associated with vitamin $D$ intake during pregnancy. Parous women had lower vitamin $D$ intake than nulliparous women and Caucasian had lower intakes of vitamin D than White women [13]. Pre-pregnancy BMI was inversely associated with vitamin $D$ intake, in which overweight or obese pregnant women had a lower intake of vitamin D compared to underweight women [13]. In addition, pregnant women who were slightly younger, overweight and with a lower education level and income were found to have a lower intake of vitamin $D[8,14,15]$. As most products that contain calcium are fortified with vitamin D [16], individuals with high calcium intake will have a higher intake of vitamin D.

In Malaysia, a recent study on the prevalence of hypovitaminosis $\mathrm{D}$ and its associated risk factors reported that nearly all $(90.4 \%)$ pregnant women in the first trimester had serum $25(\mathrm{OH}) \mathrm{D}<50 \mathrm{nmol} / \mathrm{L}$. Malays and Indians, as well as those with a lower education level, had a significantly low serum 25(OH)D level [17]. Hamid et al. showed that approx. $60 \%$ and $37 \%$ of pregnant Malay women in the second and third trimester had vitamin D deficiency (serum $25(\mathrm{OH}) \mathrm{D}<50 \mathrm{nmol} / \mathrm{L}$ ), respectively [18]. Furthermore, only multivitamin intake in the second and third trimester during pregnancy were significantly associated with a higher serum vitamin D level. Most studies placed emphasis on vitamin $D$ status in pregnant women, but very few studies examined vitamin $D$ intake and its associated factors in pregnant women. 
To date, published studies on vitamin D intake and its associated factors among pregnant women are mainly focused on western populations $[3,8,9,19]$. Despite having sunlight throughout the year, studies have documented vitamin $D$ insufficiency or deficiency to be prevalent in Malaysia, both among pregnant and non-pregnant individuals [20-24]. In populations where sun exposure is limited due to geographical location or religious/lifestyle restrictions, dependence on dietary sources for vitamin $D$ becomes essential, although the diet provides only about $5-10 \%$ of the body's requirement for vitamin D [25]. Identifying food and non-food sources (e.g. dietary supplements) of vitamin $D$ intake, as well as factors associated with vitamin $D$ intake, could better inform researchers on the development of strategies to improve the vitamin $D$ status of pregnant Malaysian women and, subsequently, their offspring.

\section{Objectives}

The present study aimed to assess vitamin D intake, identify the dietary sources of vitamin $D$ and determine factors associated with vitamin $\mathrm{D}$ intake among pregnant Malaysian women.

\section{Material and methods}

\section{Study location and respondents}

This cross-sectional study was conducted at the Seremban Maternal and Child Health ( $\mathrm{MCH}$ ) clinic in Negeri Sembilan. The respondents were pregnant women attending the $\mathrm{MCH}$ clinic for a routine antenatal check-up from November to December 2010. The selection criteria of respondents were Malaysian women aged $18-40$ years, at $13^{\text {th }}$ to $36^{\text {th }}$ weeks of gestation, singleton pregnancy and with no medical conditions during pregnancy (e.g. gestational diabetes mellitus, pre-eclampsia) or chronic diseases (e.g. heart disease, renal disease or diabetes mellitus). A total of 386 women were screened for study eligibility, but only 314 met the eligibility criteria. This number met the sample size required for the study $(81 \%$ of pregnant women met the recommended vitamin D intake; $95 \%$ confidence level; $5 \%$ precision level) [26]. The study protocol was approved by the Medical Research Ethics Committee, Universiti Putra Malaysia and the Ministry of Health Malaysia. A study information sheet was given to the respondents and informed consent was obtained from all respondents prior to data collection.

\section{Measurements}

A set of pre-tested interviewer-administered questionnaires was used to obtain information on socio-demographics (e.g. age, ethnicity, education level, household income and household size), obstetrics (e.g. gravidity and parity), dietary intake, intake of vitamin D supplements and physical activity.

\section{Dietary intake and supplementation}

A semi-quantitative food frequency questionnaire (SFFQ) modified from Blalock et al. was used to assess dietary sources of vitamin D [27]. The SFFQ consists of 26 food items that contain vitamin D. Consumption frequency was based on a 9 response-scale: never, less than once per week, 1-2 times per week, 3-4 times per week, 5-6 times per week, daily, 2 times per day, 3 times per day and more than 3 times per day. For weekly consumption, the frequencies were converted to times per day based on the midpoint of the reported frequency category for each food item. As the Malaysian Food Composition Database does not have food values of vitamin D, the United States Department of Agriculture food database and food labels of fortified foods on the market were used to esti- mate the vitamin D content of consumed foods [16]. Vitamin D intake from each food item and its percentage contribution to total vitamin $D$ intake were calculated to identify the main food sources of vitamin D. The following formula was used to calculate vitamin D intake: Vitamin D intake = consumption frequency $x$ serving size $x$ vitamin $D$ content of the food.

A two-day 24-hour dietary recall on a weekday and a weekend was used to assess the dietary intake of respondents. Dietary data was analyzed for energy and macronutrients using Nutritionist Pro Nutrient Analysis Software: Version 1.5 [28] with the Malaysian Food Composition Database [29] for intake of energy, fat and calcium. Energy and nutrient intake for 2 days was averaged to derive mean daily energy and nutrient values. Adequacy of energy and nutrients was determined based on the Recommended Nutrient Intakes (RNI) for Malaysia [30]. Women were also interviewed for information on dietary supplement use, such as types, brands, frequency and dosage of the reported supplements. Vitamin D intake from supplements was estimated from the manufacturers' product information.

\section{Physical activity}

The Global Physical Activity Questionnaire (GPAQ) was used to determine the physical activity level of pregnant women [31]. Women recalled the number of days in the last 7 days they did either or both vigorous intensity physical activity and moderate intensity activity at 3 major settings (activities at work/home, travel to and from places, recreational activities), as well as the number of hours and minutes per day they did the activities, respectively. The respective total hours of physical activity were calculated and multiplied by metabolic equivalent (MET) hours per week and the values were then categorized into low, moderate and high physical activity [31].

\section{Statistical methods}

All statistical analyses were performed using IBM SPSS 22.0. Exploratory Data Analysis was carried out to determine the normality and homogeneity of the data. The assumption of normality was examined with the Kolmogorov-Smirnov (KS) test, and all variables, except income, were normally distributed. The data was presented descriptively as frequency, percentage, mean and standard deviation for normal distributed variables and median (minimum and maximum values) for non-normal distributed variable. Univariate and multivariate logistic regression was applied to determine the associations between socio-demographics, obstetrics, energy and macronutrients intakes, supplement usage and physical activity with total vitamin D intake. In the final multivariate model, total vitamin $D$ intake was adjusted for covariates, such as ethnicity, gravidity and trimester at study entry. Statistical significance was set at $p<0.05$.

\section{Results}

Table 1 shows the characteristics of women in the second and third trimester of pregnancy. The mean age of women was $28.13 \pm 0.26$ years, with a majority being Malays $(50.3 \%)$ and having at least secondary education (61.5\%). The average week of gestation was around 28 weeks, with more than half $(57 \%)$ being in the third trimester and $43 \%$ in the second trimester. The median monthly household income was RM 2,800 (min$-\max =$ RM 900-15,000) or USD 651.55 (min-max = USD 209.43$-3,490.44)$. The mean pre-pregnancy weight and height of the women were $57.97 \pm 13.96 \mathrm{~kg}$ and $156.42 \pm 5.85 \mathrm{~cm}$, respectively. The mean pre-pregnancy Body Mass Index (BMI) was $23.65 \pm 5.29 \mathrm{~kg} / \mathrm{m}^{2}$, with approx. $21 \%$ and $13 \%$ categorized as overweight and obese, respectively. 


\begin{tabular}{|c|c|c|c|c|}
\hline Characteristics & $n$ & $\%$ & Mean \pm SD & $\begin{array}{l}\text { Median } \\
(\min -\max )\end{array}$ \\
\hline Age at entry (years) & & & $28.13 \pm 0.26$ & \\
\hline $\begin{array}{l}\text { Gestational age } \\
\text { (weeks) }\end{array}$ & & & $27.32 \pm 7.52$ & \\
\hline $\begin{array}{l}\text { Second trimester } \\
\left(13-26^{\text {th }} \text { weeks }\right)\end{array}$ & 135 & 43.0 & & \\
\hline $\begin{array}{l}\text { Third trimester } \\
\left(27-40^{\text {th }} \text { weeks }\right)\end{array}$ & 179 & 57.0 & & \\
\hline $\begin{array}{l}\text { Ethnicity } \\
\text { Malay } \\
\text { Chinese } \\
\text { Indian and Others }\end{array}$ & $\begin{array}{l}158 \\
92 \\
64 \\
\end{array}$ & $\begin{array}{l}50.3 \\
29.3 \\
20.4 \\
\end{array}$ & & \\
\hline $\begin{array}{l}\text { Education level } \\
\text { Secondary and } \\
\text { below } \\
\text { Tertiary and above }\end{array}$ & $\begin{array}{l}193 \\
121\end{array}$ & $\begin{array}{r}61.5 \\
38.5\end{array}$ & & \\
\hline $\begin{array}{l}\text { Monthly household } \\
\text { income } \\
\text { Low } \\
\text { Middle } \\
\text { High }\end{array}$ & $\begin{array}{l}125 \\
151 \\
38\end{array}$ & $\begin{array}{l}39.8 \\
48.1 \\
12.1 \\
\end{array}$ & & $\begin{array}{l}\text { RM 2,800 } \\
(900-15,000) / \\
\text { /USD 651.55 } \\
(209.43- \\
-3,490.44) \\
\end{array}$ \\
\hline $\begin{array}{l}\text { Household size } \\
\leq 2 \\
3-4 \\
\geq 5\end{array}$ & $\begin{array}{l}79 \\
145 \\
90\end{array}$ & $\begin{array}{l}25.2 \\
46.2 \\
28.6\end{array}$ & $3.87 \pm 1.84$ & \\
\hline $\begin{array}{l}\text { Gravidity } \\
1 \\
2 \\
\geq 3 \\
\end{array}$ & $\begin{array}{l}121 \\
95 \\
98 \\
\end{array}$ & $\begin{array}{l}38.5 \\
30.3 \\
31.2 \\
\end{array}$ & $2.22 \pm 1.41$ & \\
\hline $\begin{array}{l}\text { Parity } \\
0 \\
1-2 \\
\geq 3 \\
\end{array}$ & $\begin{array}{l}123 \\
151 \\
40 \\
\end{array}$ & $\begin{array}{l}39.2 \\
48.1 \\
12.7 \\
\end{array}$ & $1.10 \pm 1.24$ & \\
\hline $\begin{array}{l}\text { Height }(\mathrm{cm}) \\
\leq 154 \\
155-158 \\
>158\end{array}$ & $\begin{array}{l}114 \\
96 \\
104 \\
\end{array}$ & $\begin{array}{l}36.3 \\
30.6 \\
33.1 \\
\end{array}$ & $156.42 \pm 5.85$ & \\
\hline $\begin{array}{l}\text { Pre-pregnancy weight } \\
(\mathrm{kg})\end{array}$ & & & $57.97 \pm 13.96$ & \\
\hline $\begin{array}{l}\text { Pre-pregnancy BMI } \\
\left(\mathrm{kg} / \mathrm{m}^{2}\right) \\
\text { Underweight }(<18.5) \\
\text { Normal }(18.5-24.9) \\
\text { Overweight }(25.0- \\
\text {-29.9) } \\
\text { Obese }(\geq 30.0)\end{array}$ & $\begin{array}{l}45 \\
160 \\
67 \\
42\end{array}$ & $\begin{array}{l}14.3 \\
51.0 \\
21.3 \\
\\
13.4\end{array}$ & $23.65 \pm 5.29$ & \\
\hline
\end{tabular}

${ }^{*} 10^{\text {th }}$ Malaysia Plan - Low household income is defined as $<$ RM 2,300 (< USD 535.20); middle household income as RM 2,300-5,599 (USD 535.20 $-1,302.87$ ); high household income as $\geq$ RM 5,600 ( $\geq$ USD 1,303.10).

One-third (35.4\%) of women had a low physical activity level (Table 2). The mean energy intake of women was $1,376 \pm 27.08$ kcal ( $55.3 \%$ of $\mathrm{RNI})$, with $11.2 \%$ having sufficient energy intake. The mean calcium intake of women was $800.23 \pm 34.88 \mathrm{mg}$, with approx. $80 \%$ of RNI for calcium being met. More than half of the women $(61.8 \%)$ had an intake less than RNI for calcium, and $17.2 \%$ had achieved RNI for calcium of $1,000 \mathrm{mg}$ per day. The mean total vitamin $D$ intake was $11.54 \pm 0.45 \mu \mathrm{g} /$ day, with $6.55 \pm 4.43 \mu \mathrm{g} /$ day from food sources and $4.99 \pm 5.95 \mu \mathrm{g} /$ day from dietary supplements. Nearly half $(47.5 \%)$ of the women were taking vitamin $\mathrm{D}$ supplements. Milk and milk products showed the greatest contribution to vitamin D intake (56.8\%), followed by cereals (17.1\%), beverages (12.4\%), meat and meat products (12.4\%) and spreads (1.3\%) (Table 3 ).

\begin{tabular}{|c|c|c|c|}
\hline Characteristics & $n$ & $\%$ & Mean \pm SD \\
\hline $\begin{array}{l}\text { Physical activity level } \\
\text { Low } \\
\text { Moderate } \\
\text { High }\end{array}$ & $\begin{array}{l}111 \\
132 \\
71\end{array}$ & $\begin{array}{l}35.4 \\
42.0 \\
22.6\end{array}$ & \\
\hline Energy (kcal) & & & $1376 \pm 27.08$ \\
\hline $\begin{array}{l}\text { Percentage RNI for energy } \\
<75 \% \\
75-100 \% * \\
101-125 \%\end{array}$ & $\begin{array}{l}272 \\
35 \\
7\end{array}$ & $\begin{array}{l}86.6 \\
11.2 \\
2.2\end{array}$ & $55.33 \pm 19.01$ \\
\hline $\begin{array}{l}\text { Percentage energy from } \\
\text { carbohydrate } \\
<55 \% \\
55-70 \% * \\
>70 \%\end{array}$ & $\begin{array}{l}220 \\
81 \\
13\end{array}$ & $\begin{array}{l}70.1 \\
25.8 \\
4.1\end{array}$ & $37.72 \pm 1.18$ \\
\hline $\begin{array}{l}\text { Percentage energy from } \\
\text { protein } \\
<10 \% \\
10-15 \% * \\
>15 \% \\
\end{array}$ & $\begin{array}{l}2 \\
38 \\
274 \\
\end{array}$ & $\begin{array}{l}0.6 \\
12.1 \\
87.3 \\
\end{array}$ & $36.85 \pm 1.16$ \\
\hline $\begin{array}{l}\text { Percentage energy from fat } \\
<20 \% \\
20-30 \% * \\
>30 \%\end{array}$ & $\begin{array}{l}67 \\
171 \\
76\end{array}$ & $\begin{array}{l}21.3 \\
54.5 \\
24.2\end{array}$ & $25.45 \pm 0.40$ \\
\hline Calcium (mg) & & & $800.23 \pm 34.88$ \\
\hline $\begin{array}{l}\text { Percentage RNI for calcium } \\
<75 \% \\
75-100 \% * \\
101-125 \% \\
>125 \%\end{array}$ & $\begin{array}{l}194 \\
26 \\
28 \\
66\end{array}$ & $\begin{array}{l}61.8 \\
8.3 \\
8.9 \\
21.0\end{array}$ & $80.03 \pm 3.49$ \\
\hline $\begin{array}{l}\text { Vitamin D }(\mu \mathrm{g}) \\
\text { Food } \\
\text { Supplement }\end{array}$ & 149 & 47.5 & $\begin{array}{l}11.54 \pm 0.45 \\
6.55 \pm 4.43 \\
4.99 \pm 5.95\end{array}$ \\
\hline $\begin{array}{l}\text { Percentage RNI for vitamin D } \\
<75 \% \\
75-100 \% * \\
101-125 \% \\
>125 \%\end{array}$ & $\begin{array}{l}55 \\
25 \\
25 \\
209\end{array}$ & $\begin{array}{l}17.5 \\
8.0 \\
8.0 \\
66.5 \\
\end{array}$ & $230.84 \pm 8.95$ \\
\hline $\begin{array}{l}\text { Vitamin } D \text { categories } \\
\text { Below recommendation } \\
\text { level }(<5 \mu \mathrm{g} / \text { day) } \\
\text { Above recommendation } \\
\text { level ( } \geq 5 \mu \mathrm{g} / \text { day) }\end{array}$ & $\begin{array}{l}80 \\
234\end{array}$ & $\begin{array}{l}25.5 \\
74.5\end{array}$ & \\
\hline
\end{tabular}

*Recommended level - Energy intake: $19-29$ years of age $\left(2^{\text {nd }}\right.$ trimester $-2,360 \mathrm{kcal} /$ day; $3^{\text {rd }}$ trimester $\left.-2,470 \mathrm{kcal} / \mathrm{day}\right), 30-59$ of age $\left(2^{\text {nd }}\right.$ trimester $-2,540 \mathrm{kcal} /$ day; $3^{\text {rd }}$ trimester $-2,650 \mathrm{kcal} /$ day); Calcium: 1,000 $\mathrm{mg} /$ day; Vitamin D: $5 \mu \mathrm{g} /$ day (Source: Malaysia Recommended Nutrient Intakes (RNI), 2005).

Table 3. Contribution of food items to the vitamin D intake

\section{of pregnant women}

Food item

Contribution

(\%)

Milk and milk products

Fresh milk

56.82

Maternal milk powder ${ }^{a}$

27.50

25.13

Milk powder (Full cream milk/Low-fat milk) 2.79

\begin{tabular}{l|l} 
Sweetened condensed creamer & 0.72
\end{tabular}

Cheese

Evaporated creamer

0.72
0.37

Yogurt 


\begin{tabular}{|l|l|}
\hline $\begin{array}{l}\text { Table 3. Contribution of food items to the vitamin D intake } \\
\text { of pregnant women }\end{array}$ \\
\hline Food item & $\begin{array}{l}\text { Contribution } \\
\text { (\%) }\end{array}$ \\
\hline Cereals & 17.08 \\
Breads & 16.04 \\
Biscuits & 1.04 \\
\hline Beverages & 12.43 \\
Malted drinks & 9.00 \\
Cereal drinks & 1.97 \\
Cultured milks & 1.46 \\
\hline Meat and meat products & 12.43 \\
Egg & 3.74 \\
Salmon & 3.14 \\
Sardine & 2.66 \\
Cod & 0.96 \\
Herring & 0.72 \\
Pork & 0.63 \\
Liver & 0.50 \\
Beef & 0.08 \\
\hline Spreads & 1.25 \\
Margarine & 1.25 \\
\hline
\end{tabular}

aMaternal milk powder - milk based maternal supplement containing macronutrients and essential vitamins and minerals that are formulated to support the increased nutritional needs for pregnant women. The estimated vitamin $D$ intake from food $(6.55 \pm 4.43 \mu \mathrm{g} /$ day) was based on a semi-quantitative food frequency questionnaire.

Women with an intake of energy (crude $\mathrm{OR}=0.18,95 \% \mathrm{Cl}$ $=0.03-0.76$ ) and calcium (crude $\mathrm{OR}=0.27,95 \% \mathrm{Cl}=0.12-0.63$ ) above recommendation levels and obese women (crude OR $=1.97,95 \% \mathrm{Cl}=1.96-4.07$ ) were independently associated with inadequate vitamin $\mathrm{D}$ intake (data not shown). In the final logistic model, women with energy (adjusted $\mathrm{OR}=0.10,95 \% \mathrm{Cl}$ $=0.01-0.87$ ) and calcium (adjusted $\mathrm{OR}=0.27,95 \% \mathrm{Cl}=0.11-$ -0.67 ) intake above recommendation levels were less likely to have inadequate vitamin $D$ intake. Overweight women (adjusted $\mathrm{OR}=1.25,95 \% \mathrm{Cl}=0.60-2.58$ ) and obese women (adjusted $\mathrm{OR}=1.65,95 \% \mathrm{Cl}=0.72-3.79)$ tend to have a vitamin $\mathrm{D}$ intake below recommendation levels (Table 4).

\begin{tabular}{|c|c|c|}
\hline & $\begin{array}{l}\text { Vitamin D intake } \\
\text { (below recommen- } \text { dation level) }{ }^{\mathrm{a}}\end{array}$ & $p$ \\
\hline & Adjusted OR (CI) & \\
\hline $\begin{array}{l}\text { Percentage RNI for energy } \\
<75 \% \\
75-100 \% \\
101-125 \%\end{array}$ & $\begin{array}{l}1.00 \\
0.14(0.02-0.97) \\
0.10(0.03-0.87)\end{array}$ & $\begin{array}{l}0.05 \\
0.04 *\end{array}$ \\
\hline $\begin{array}{l}\text { Pre-pregnancy BMI }\left(\mathrm{kg} / \mathrm{m}^{2}\right)^{\mathrm{c}} \\
\text { Underweight }(<18.5) \\
\text { Normal }(18.5-24.9) \\
\text { Overweight }(25.0-29.9) \\
\text { Obese }(\geq 30.0)\end{array}$ & $\begin{array}{l}0.81(0.32-2.06) \\
1.00 \\
1.25(0.60-2.58) \\
1.65(1.72-3.79)\end{array}$ & $\begin{array}{l}0.65 \\
0.55 \\
0.02 *\end{array}$ \\
\hline $\begin{array}{l}\text { Percentage RNI for calcium } \\
<75 \% \\
75-100 \% \\
101-125 \% \\
>125 \%\end{array}$ & $\begin{array}{l}1.00 \\
1.18(0.44-3.16) \\
0.37(0.12-1.33) \\
0.27(0.11-0.67)\end{array}$ & $\begin{array}{l}0.74 \\
0.13 \\
0.01 *\end{array}$ \\
\hline
\end{tabular}

${ }^{a}$ The reference category is vitamin D intake above recommendation levels ( $\geq 5 \mu \mathrm{g} /$ day); badjusted for ethnicity, gravidity, pre-pregnancy BMI and trimester at study entry; 'adjusted for ethnicity, gravidity and trimester at study entry.

${ }^{*} p<0.05$; non-significant factors: supplement usage, physical activity level, percentage energy from carbohydrate, percentage energy from protein and percentage energy from fat.

\section{Discussion}

The present study showed that about $74.5 \%$ of pregnant women met the recommended intake of vitamin $D(5 \mu \mathrm{g} /$ day $)$, and that the mean vitamin $D$ intake from diet and dietary supplements was $6.55 \pm 4.43 \mu \mathrm{g} /$ day and $4.99 \pm 5.95 \mu \mathrm{g} /$ day, respectively. Nearly half $(47.1 \%)$ of these women were taking vitamin D supplements. Milk and milk products showed the greatest contribution to vitamin D intake (56.8\%). Women with a higher energy and calcium intake were more likely to have adequate vitamin D intake, while obese women were less likely to have adequate vitamin $D$ intake.

According to IOM (1997), there is no evidence of additional requirements for vitamin $D$ during pregnancy, as the placental transfer of vitamin $D$ from mother to fetus is apparently minute [32]. A review by Specker also reported that there is no evidence to indicate that higher vitamin $D$ intake is needed during pregnancy to prevent vitamin $D$ deficiency compared to non-pregnant women [33]. However, Cashman et al. reported that a vitamin D intake of $10 \mu \mathrm{g} /$ day is needed to ensure sufficient vitamin D status [34]. With increasing evidence to support a higher recommendation for vitamin D intake, IOM reevaluated the existing recommendations of vitamin D intake and suggested new Dietary Reference Intakes (DRIs) for vitamin D for all ages and elderly people over 70 years of age to be $15 \mu \mathrm{g} /$ /day and $20 \mu \mathrm{g} /$ day, respectively [35]. However, in Malaysia, the Recommended Nutrient Intakes (RNI) for vitamin D intake for pregnant and lactating women is set at $5 \mu \mathrm{g} /$ day, which is the same as for non-pregnant women [30]. In the present study, the mean total vitamin D intake was $11.54 \pm 0.45 \mu \mathrm{g} /$ day, with about $75 \%$ of women meeting the recommended level of vitamin D, which is $5 \mu \mathrm{g} /$ day. In the United States (US) and Cana$\mathrm{da}$, the recommended dietary allowance is $15 \mu \mathrm{g}$ per day [35]. Therefore, if the recommendations of vitamin $D$ intake for pregnant women in the present study is set at $10 \mu \mathrm{g} /$ day and $15 \mu \mathrm{g} /$ /day, approx. $50 \%$ and $68 \%$ of pregnant women will be reported as having insufficient vitamin D intake, respectively (data no shown). These findings are in line with previous studies reporting that more than half of pregnant women in Norway $(63 \%)$, Finland (85\%) and the US (50\%) did not meet the recommended vitamin $D$ intake of $10 \mu \mathrm{g}$ per day $[3,13,36]$.

Although the present study did not measure the vitamin D status of women, they are expected to be at higher risk of vitamin D deficiency for several reasons. The human body obtains vitamin $D$ from both dietary sources and synthesis in the skin through exposure to sunlight [37]. The mean vitamin D intake of $11.54 \pm 0.45 \mu \mathrm{g} /$ day in the present study was far below the IOM recommended level of $15 \mu \mathrm{g} /$ day, which was established based on the amount of intake necessary to sustain blood levels of 25(OH)D above $50 \mathrm{nmol} / \mathrm{l}$ for populations with minimal sunlight exposure [35]. Although Malaysia receives plenty of sunshine year round, previous studies showed that the majority (60-90\%) of pregnant women have serum 25(OH)D below $50 \mathrm{nmol} / \mathrm{l}[17$, 18]. In addition, women in Malaysia tend to reduce sunshine exposure due to covered dress (religious practice) or use of sunscreen for either cosmetic reasons or to prevent skin damage $[38,39]$. The use of sunscreen could block UV light and subsequently inhibit vitamin D production [40]. Moreover, nearly all (98\%) pregnant women in the present study were housewives and indoor workers (data not shown), which could contribute to them having a lower duration of sun exposure.

Nearly half $(47.5 \%)$ of the women in the present study were taking dietary supplements containing vitamin $\mathrm{D}$, such as multivitamins $(43.6 \%)$, cod liver oil $(1.9 \%)$ or both (2\%) (data not shown). However, none of the women were taking any single vitamin D2 or D3 supplement, which could be due to this vitamin supplement being only taken in single form for certain medical conditions or being prescribed by physicians. It was also noted that these women were taking multivitamins and cod liver oil not because of vitamin $D$, but for other nutrients. Lack of aware- 
ness on the importance of vitamin $D$ for the health of women and children and the benefits of vitamin D supplements, as well as concerns about the side-effects of vitamin D supplements, is still prevalent among pregnant women in the present study. Nevertheless, almost $75 \%$ of these women achieved the recommended vitamin $D$ intake through foods and dietary supplements.

Food sources of vitamin D may vary across cultures due to food preferences and tolerances. In the present study, the major food sources of vitamin $\mathrm{D}$ in the diet of pregnant Malaysian women were dairy products (fresh milk, maternal milk powder, full cream milk, creamer, cheese and yogurt) and cereals (breads and biscuits). In contrast, fish, seafood, low-fat dairy products and eggs were predominant sources of vitamin $D$ in the diets of pregnant Danish women [2]. Similarly, the National Health and Nutrition Survey of Japan also revealed that fish and shellfish were the main sources of vitamin $D$ among Japanese [41]. Although fish contains considerable amounts of vitamin D, the consumption of fish in the present study was very low, with only about $7.5 \%$ of vitamin $D$ being derived from these foods. The lower fish intake may be due to the higher cost of fish rich in vitamin D (e.g. salmon, trout and mackerel), as about $87.9 \%$ of women were in low- and middle-income groups. Besides the cost, the availability and accessibility of food may influence individual food choices. In Malaysia, cereals and dairy products, such as breads, biscuits and milk powder, are readily available in grocery stores, minimarkets or sundry shops, which are accessible to a majority of the population. Furthermore, pregnant women generally increase their intakes of dairy products for the health of their babies [42].

In the present study, obese women were more likely to have lower vitamin D intake. Similarly, Scholl and Chen reported that pre-pregnancy BMI correlated inversely with total vitamin D intake [13]. Obese individuals tend to avoid milk and dairy products due to the misconception that these products are fattening [43]. They were also more likely to avoid foods such as cod liver oil, cheese and margarine, which are good sources of vitamin D $[44,45]$. Lower vitamin $D$ intake and lack of sun exposure could put these obese pregnant women at risk of a poor vitamin $D$ status [46].

This study also found that women with higher calcium intake were less likely to have inadequate vitamin D intake. This finding was consistent with several studies, which reported that calcium intake was highly correlated with vitamin D intake [8, $47,48]$. Most of the products that contain calcium are fortified with vitamin $D[16,49]$. For example, high calcium foods, such as milk, milk products, yogurt and cheese, are often fortified with vitamin D. Similar to previous studies $[50,51]$, the present study also found that higher energy intake was associated with adequate vitamin $D$ intake. The association between vitamin $D$ intake and energy intake could be explained by the energy and fat content of dairy products. In the present study, about twothirds of vitamin $D$ were derived from dairy products. Among the dairy products, fresh milk and maternal milk contributed the most, which generally contain higher energy and fat. Although not all dairy products have high energy and fat content, choosing dairy products seems to increase vitamin $D$ intake, as well as the total intake of daily calories.

\section{Limitations of the study}

The present study is not without limitations. The recruitment of pregnant women from only one $\mathrm{MCH}$ clinic in Seremban, as well as the short duration of recruitment (i.e. only women attending antenatal care during this period were recruited into the study), could introduce bias to the study and limit the generalization of the study findings to all pregnant women in Malaysia. A 3-day, 24-hour diet recall is recommended for better estimation of the energy and nutrient intake of individuals. However, the respondents in the present study felt burdened with the in-depth questioning of food consumption (24-hour diet recall and semi-quantitative food frequency questionnaire (SFFQ)). Thus, a 2-day, 24-hour diet recall and SFFQ were used to estimate energy, macronutrients, calcium and vitamin $D$ intake, respectively. Although the results generated may not reflect habitual dietary intake, Ma et al. showed that a 2-day, 24-hour diet recall improved the findings of a single diet recall [52]. Furthermore, while a dietary recall is known to underestimate intake, overestimation could occur with food frequency. In this study, approximately $70 \%$ of pregnant women under-reported their daily energy intake despite efforts to assist them to recall intake, i.e. use of household measures and a food album of commonly consumed foods. However, all data was used in the analysis, as it was well within \pm 3 SD of mean energy intake [53]. The use of the United States Department of Agriculture food database to estimate the vitamin D content of foods might yield overestimated values. However, it is not expected that there is much difference in the vitamin $D$ content of vitamin $D$ fortified foods on the market with those available in the USDA food database (e.g. breads, milk, margarine/spreads). As the study only assessed vitamin D intake, it cannot relate the intake to vitamin D status (blood level of 25-hydroxyvitamin D). Sun exposure, which was not measured in the present study, could be a major contributing factor to the women's vitamin D status, regardless of their vitamin D intake. Despite these limitations, this study does provide information on the vitamin $D$ intake of pregnant women, which could add to the limited literature on the dietary intake and sources of vitamin D of pregnant Malaysian women.

\section{Conclusions}

This study showed that most pregnant women met the recommendation level of vitamin D intake through food and dietary supplements. However, they might not have sufficient vitamin $D$ intake to maintain an adequate vitamin $D$ status throughout pregnancy, as the average intake was still below the IOM recommendation level of $15 \mu \mathrm{g} /$ day. Pre-pregnancy BMI and intake of energy and calcium were significantly associated with vitamin D intake. More studies are needed to confirm these findings and relate the intake of vitamin $D$ from foods and dietary supplements to the vitamin D status of pregnant women.

Acknowledgements. The authors would like to thank all the staff at the Seremban $\mathrm{MCH}$ clinic, Negeri Sembilan, for their assistance during data collection.

Source of funding: This work was funded by the authors' own resources.

Conflict of interest: The authors declare no conflict of interests.

\section{References}

1. Ray JA, Meikle AW. D-light: vitamin D and good health. MLO Med Lab Obs 2010; 42(5): 32-38.

2. Jensen CB, Petersen SB, Granström C, et al. Sources and determinants of vitamin D intake in Danish pregnant women. Nutrients 2012; 4(12): 259-272, doi: 10.3390/nu4040259.

3. Marjamäki L, Niinistö S, Kenward MG, et al. Maternal intake of vitamin D during pregnancy and risk of advanced beta cell autoimmunity and type 1 diabetes in offspring. Diabetologia 2010; 53(8): 1599-1607, doi: 10.1007/s00125-010-1734-8. 
4. Wei S-Q, Qi H-P, Luo Z-C, et al. Maternal vitamin D status and adverse pregnancy outcomes: a systematic review and meta-analysis. J Matern Fetal Neonatal Med 2013; 26(9): 889-899, doi: 10.3109/14767058.2013.765849.

5. Baker AM, Haeri S, Camargo CA, et al. A nested case-control study of midgestation vitamin D deficiency and risk of severe preeclampsia. J Clin Endocrinol Metab 2010; 95(11): 5105-5109, doi: 10.1210/jc.2010-0996.

6. Dror DK. Vitamin D status during pregnancy: maternal, fetal, and postnatal outcomes. Curr Opin Obstet Gynecol 2011; 23(6): 422-426, doi: 10.1097/GCO.0b013e32834cb791.

7. Durie DE, Thornburg LL, Glantz JC. Effect of second-trimester and third-trimester rate of gestational weight gain on maternal and neonatal outcomes. Obstet Gynecol 2011; 118(3): 569-575.

8. Devereux G, Litonjua AA, Turner SW, et al. Maternal vitamin D intake during pregnancy and early childhood wheezing. Am J Clin Nutr 2007; 85(3): 853-859.

9. McGowan C, Byrne J, Walsh J, et al. Insufficient vitamin D intakes among pregnant women. Eur J Clin Nutr 2011; 65(9): 1076-1078, doi: 10.1038/ejcn.2011.110.

10. Erkkola $\mathrm{M}$, Kaila $\mathrm{M}, \mathrm{Nwaru} \mathrm{BI}$, et al. Maternal vitamin $\mathrm{D}$ intake during pregnancy is inversely associated with asthma and allergic rhinitis in 5-year-old children. Clin Exp Allergy 2009; 39(6): 875-882, doi: 10.1111/j.1365-2222.2009.03234.x.

11. Esmaillzadeh A, Samareh S, Azadbakht L. Dietary patterns among pregnant women in the west-north of Iran. Pakistan J Biol Sci PJBS 2008; 11(5): 793-796.

12. Sabour H, Hossein-Nezhad A, Maghbooli Z, et al. Relationship between pregnancy outcomes and maternal vitamin D and calcium intake: a cross-sectional study. Gynecol Endocrinol 2006; 22(10): 585-589.

13. Scholl TO, Chen X. Vitamin D intake during pregnancy: association with maternal characteristics and infant birth weight. Early Hum Dev 2009; 85(4): 231-234, doi: 10.1016/j.earlhumdev.2008.10.006.

14. Arkkola T, Uusitalo U, Pietikainen M, et al. Dietary intake and use of dietary supplements in relation to demographic variables among pregnant Finnish women. Br J Nutr 2006; 96(5): 913-920.

15. Camargo CA, Rifas-Shiman SL, Litonjua AA, et al. Maternal intake of vitamin D during pregnancy and risk of recurrent wheeze in children at 3 y of age. Am J Clin Nutr 2007; 85(3): 788-795.

16. U.S. Department of Agriculture ARS. USDA National Nutrient Database for Standard Reference, Release 27. Nutr Data Lab 2014; 5(1): 2-11, doi: 10.13140/RG.2.1.3992.3443.

17. Bukhary NBI, Isa ZM, Shamsuddin K, et al. Risk factors for antenatal hypovitaminosis D in an urban district in Malaysia. BMC Pregnancy Childbirth 2016; 16(1): 156, doi: 10.1186/s12884-016-0939-3.

18. Hamid JJM, Rowan A, Fong B, et al. Maternal serum and breast milk vitamin D levels: findings from the Universiti Sains Malaysia Pregnancy Cohort Study. PLoS ONE 2014; 9(7): e100705, doi: 10.1371/journal.pone.0100705.

19. Erkkola $M$, Karppinen $M$, Järvinen $A$, et al. Folate, vitamin $D$, and iron intakes are low among pregnant Finnish women. Eur J Clin Nutr 1998; 52(10): 742-748.

20. McAree T, Jacobs B, Manickavasagar T, et al. Vitamin D deficiency in pregnancy - still a public health issue. Matern Child Nutr 2013; 9(1): 23-30, doi: 10.1111/mcn.12014.

21. Richard A, Rohrmann S, Quack Lötscher KC. Prevalence of vitamin D deficiency and its associations with skin color in pregnant women in the first trimester in a sample from Switzerland. Nutrients 2017; 9(3), doi: 10.3390/nu9030260.

22. Chin KY, Ima-Nirwana S, Ibrahim S, et al. Vitamin D status in Malaysian men and its associated factors. Nutrients 2014; 6(12): 5419$-5433$.

23. Khor GL, Chee WSS, Zalilah MS, et al. High prevalence of vitamin D insufficiency and its association with BMI-for-age among primary school children in Kuala Lumpur, Malaysia. BMC Public Health 2011; 11(1): 95, doi: 10.1186/1471-2458-11-95.

24. Shafinaz IS, Moy FM. Vitamin D level and its association with adiposity among multi-ethnic adults in Kuala Lumpur, Malaysia: a cross sectional study. BMC Public Health 2016; 16: 232, doi: 10.1186/s12889-016-2924-1.

25. Nowson CA, McGrath JJ, Ebeling PR, et al. Vitamin D and health in adults in Australia and New Zealand: a position statement. Med J Aust 2012; 196(11): 686-687.

26. Sullivan LM. Essentials of biostatistics in public health. Sudbury (MA): Jones and Bartlett Publishers, Inc; 2008.

27. Blalock SJ, Norton LL, Patel RA, et al. Development and assessment of a short instrument for assessing dietary intakes of calcium and vitamin D. J Am Pharm Assoc 2003; 43(6): 685-693.

28. First Data Bank. Nutritionist Pro. San Bruno, CA 94066. 2005.

29. Tee ES, Noor MI, Azudin MN, et al. Nutrient Composition of Malaysia foods. 4th ed. Kuala Lumpur: Institute of Medical Research, Ministry of Health, Malaysia; 1997.

30. National Coordinating Committee on Food and Nutrition. Recommended nutrient intakes for Malaysia. A report of the technical working group on nutritional guidelines. Putrajaya: Ministry of Health Malaysia; 2005.

31. Armstrong T, Bull F. Development of the World Health Organization Global Physical Activity Questionnaire (GPAQ). J Public Health 2006; 14(2): 66-70, doi: https://doi.org/10.1007/s10389-006-0024-x.

32. Institute of Medicine (US) Standing Committee on the Scientific Evaluation of Dietary Reference Intakes. Dietary Reference Intakes for calcium, phosphorus, magnesium, vitamin D, and fluoride. Washington (DC): National Academies Press; 1997.

33. Specker B. Vitamin D requirements during pregnancy. Am J Clin Nutr 2004; 80(6 Suppl.): 1740S-1770S.

34. Cashman KD, Hill TR, Lucey AJ, et al. Estimation of the dietary requirement for vitamin D in healthy adults. Am J Clin Nutr 2008; 88(6): 1535-1542, doi: 10.3945/ajcn.2008.26594.

35. Institute of Medicine (US) Committee to Review Dietary Reference intakes for Vitamin D and Calcium. Dietary reference intakes for calcium and vitamin D. Washington (DC): National Academies Press; 2011.

36. Haugen $\mathrm{M}$, Brantsaeter AL, Alexander J, et al. Dietary supplements contribute substantially to the total nutrient intake in pregnant Norwegian women. Ann Nutr Metab 2008; 52(4): 272-280, doi: 10.1159/000146274.

37. Food and Nutrition Board Institute of Medicine. Dietary Reference Intakes for Calcium and Vitamin D [Internet]. The National Academies Press 2011. Available from: http://www.nap.edu/catalog/13050/dietary-reference-intakes-for-calcium-and-vitamin-d.

38. Mithal A, Wahl DA, Bonjour JP, et al. Global vitamin D status and determinants of hypovitaminosis D. Osteoporos Int 2009; 20(11): 1807-1820, doi: 10.1007/s00198-009-0954-6.

39. Moy FM, Bulgiba A. High prevalence of vitamin D insufficiency and its association with obesity and metabolic syndrome among Malay adults in Kuala Lumpur, Malaysia. BMC Public Health 2011; 11: 735, doi: 10.1186/1471-2458-11-735.

40. Shiraishi $M$, Haruna $M$, Matsuzaki $M$, et al. Demographic and lifestyle factors associated with vitamin $D$ status in pregnant Japanese women. J Nutr Sci Vitaminol (Tokyo) 2014; 60(6): 420-428, doi: 10.3177/jnsv.60.420.

41. National Institute of Health and Nutrition. National Nutrition Survey in Japan. National Institute of Health and Nutrition; 2012. Available from URL: http://www.nibiohn.go.jp/eiken/english/research/project_nhns.html.

42. Verbeke W, De Bourdeaudhuij I. Dietary behaviour of pregnant versus non-pregnant women. Appetite 2007; 48(1): 78-86. 
43. Mirmiran P, Esmaillzadeh A, Azizi F. Dairy consumption and body mass index: an inverse relationship. Int J Obes (London) 2005; 29(1): 115-121.

44. Lahti-Koski M, Pietinen P, Heliövaara M, et al. Associations of body mass index and obesity with physical activity, food choices, alcohol intake, and smoking in the 1982-1997 FINRISK Studies. Am J Clin Nutr 2002; 75(5): 809-817.

45. Molarius A. The contribution of lifestyle factors to socioeconomic differences in obesity in men and women - a population-based study in Sweden. Eur J Epidemiol 2003; 18(3): 227-234.

46. Bolland MJ, Grey AB, Ames RW, et al. The effects of seasonal variation of 25-hydroxyvitamin D and fat mass on a diagnosis of vitamin D sufficiency. Am J Clin Nutr 2007; 86(4): 959-964.

47. Liu S, Song Y, Ford ES, et al. Dietary calcium, vitamin D, and the prevalence of metabolic syndrome in middle-aged and older U.S. women. Diabetes Care 2009; 28(12): 2926-2932.

48. Skinner HG, Michaud DS, Giovannucci E, et al. Vitamin D intake and the risk for pancreatic cancer in two cohort studies. Cancer Epidemiol Biomarkers Prev 2006; 15(9): 1688-1695.

49. Merlino L, Curtis J, Mikuls T, et al. Vitamin D intake is inversely associated with rheumatoid arthritis: results from the lowa Women's Health Study. Arthritis Rheum 2004; 50(1): 72-77.

50. Robien K, Cutler GJ, Lazovich D. Vitamin D intake and breast cancer risk in postmenopausal women: the lowa Women's Health Study. Cancer Causes Control 2007; 18(7): 775-782.

51. Willett W, Stampfer MJ. Total energy intake: implications for epidemiologic analyses. Am J Epidemiol 1986; 124(1): 17-27.

52. Ma Y, Olendzki BC, Pagoto SL, et al. Number of 24-hour diet recalls needed to estimate energy intake. Ann Epidemiol 2009; 19(8): 553-559.

53. Terry P, Hu FB, Hansen $\mathrm{H}$, et al. Prospective study of major dietary patterns and colorectal cancer risk in women. Am J Epidemiol 2001; 154(12): 1143-1149.

Tables: 4

Figures: 0

References: 53

Received: 10.02.2017

Revised: 30.06.2017

Accepted: 10.07.2017

Address for correspondence:

Mohd Shariff Zalilah, PhD

Department of Nutrition and Dietetics

Faculty of Medicine and Health Sciences

Universiti Putra Malaysia

Serdang 43400 Selangor

Malaysia

Tel.: 03-89472472

E-mail: zalilahms@upm.edu.my 